\title{
Professional Science Graduate Program Revolutionizes the Educational Ex- perience of Engineers
}

\section{Dr. Saeed D. Foroudastan, Middle Tennessee State University}

Dr. Saeed Foroudastan is the Associate Dean for the College of Basic and Applied Sciences (CBAS). The CBAS oversees 10 departments at Middle Tennessee State University. He is also the current Director for the Masters of Science in Professional Science program and a professor of engineering technology at MTSU. Foroudastan received his B.S. in civil engineering, his M.S. in civil engineering, and his Ph.D. in mechanical engineering from Tennessee Technological University. Additionally, he has six years of industrial experience as a Senior Engineer and 18 years of academic experience as a professor, Associate Professor, and Assistant Professor. Foroudastan's academic experience includes teaching at Tennessee Technological University and Middle Tennessee State University in the areas of civil engineering, mechanical engineering, and engineering technology. He has actively advised undergraduate and graduate students, alumni, and minority students in academics and career guidance. Foroudastan has also served as Faculty Advisor for SAE, Mechanical Engineering Technology, Pre-engineering, ASME, Experimental Vehicles Program (EVP), and Tau Alpha Pi Honors Society. In addition to Foroudastan's teaching experience, he also has performed extensive research and published numerous technical papers. He has secured more than $\$ 2$ million in the form of both internal and external grants and research funding. Foroudastan is the faculty advisor, coordinator, and primary fundraiser for EVP teams entering national research project competitions such as the Formula SAE Collegiate Competition, the Baja SAE Race, the SolarBike Race, the Great Moonbuggy Race, and the Solar Boat Collegiate Competition. For his concern for and dedication to his students, Foroudastan received MTSU awards such as the 2002-03 Outstanding Teaching Award, the 2005-06 Outstanding Public Service Award, and the 2007 Faculty Advisor of the Year Award. He received the Excellence in Engineering Education Award and Faculty Advisor Award from the Society of Automotive Engineers (SAE). He was also nominated for the MTSU 2005 and 2009-11 Outstanding Research Award. He received two Academic Excellence awards from the Tennessee Board of Region in 2010-11. Foroudastan has also won many College of Basic and Applied Science awards. In addition to this, Foroudastan also reviews papers for journals and conference proceedings of ASEE, ASEE-SE, and ASME, and he has been a session moderator for several professional conferences.

\section{Ms. Karly Anne Danhausen, Middle Tennessee State University}

Ms. Karly A. Danhausen holds a Bachelor of Science in Biomedical Science from Grand Valley State University. She is currently pursuing a Master of Science in Professional Science from Middle Tennessee State University. Danhausen is one of the graduate assistants for the Director of the Master of Science in Professional Science program and Associate Dean of the College of Basic and Applied Sciences, Dr. Saeed Foroudastan. Danhausen is responsible for reviewing and critiquing research literature, and also assists in composing grants and technical papers for publication. Danhausen is Vice President of the Master of Science in Professional Science club, and collaborates with other officers to organize professional networking opportunities for MS-PS students.

\section{Ms. Chelsea Rae Nihill, Middle Tennessee State University}

Ms. Chelsea R. Nihill received a Bachelor of Science degree in Chemistry from Middle Tennessee State University. She is currently pursuing a Master of Science in Professional Science from Middle Tennessee State University. Nihill is President of the Master of Science in Professional Science club, and one of the graduate assistants for the Director of the Master of Science in Professional Science program and Associate Dean of the College of Basic and Applied Sciences, Dr. Saeed Foroudastan. Nihill's responsibilities are reviewing and critiquing research literature and assisting in composing grants and technical papers for publication. 


\title{
Professional Science Graduate Degree Revolutionizes the Educational Experience for Engineers
}

\begin{abstract}
The Master of Science in Professional Science (MSPS) program at Middle Tennessee State University is a two-year graduate program that offers students a professional degree in science, technology, engineering, and mathematics disciplines, and satisfies the Professional Science Master's requirements. This innovative program is the way of the future, and is designed to fit the unmet needs of today's industry. The current workforce demands experienced professionals who are able to integrate science or mathematical expertise with proficiency in leadership, management, and interpersonal skills. It's not only crucial to comprehend and understand complex research, it's vital to be able to communicate that information to individuals who may not possess equivalent scientific intelligence. ${ }^{6}$ The curriculum is structured to give students a competitive edge in the global market by creating a new breed of scientist that is able to bridge the gap between science and business. Many students find that searching for a job after graduation can be daunting, and they lack the experience necessary for hiring. However, earning a MSPS degree is comparable to having 1-2 years of experience before even entering the workplace. With 21 hours of core classes and 15 hours of business and managerial classes, students are able to expand upon their science education, along with growing their business acumen.
\end{abstract}

During the last semester of their graduate degree, students are required to complete a 250-hour internship at a company that relates to their field of study. They obtain real-world, industry experience, along with hands-on training, networking, team building, and educational opportunities, which aren't always provided in an ordinary classroom setting. Students complete an exit interview at the end of the internship, and a staggering 70 percent report that they are offered a job from the company they completed their internship at contingent upon graduating from the MSPS program. ${ }^{7}$ Once students have fulfilled their internship requirement, they give a professional presentation to their fellow MSPS colleagues, MSPS faculty, and other industry employers who choose to attend. This is a great opportunity for students to showcase the projects they worked on, technical skills they acquired, and their overall experience as a real employee. This is not only a chance for the individual to practice and exercise communication and presenting skills, but also an opportunity for other MSPS students who haven't completed an internship to see what types of internship positions are available to them. This groundbreaking program is one of the fastest growing graduate programs at Middle Tennessee State University, and it continues to effectively groom students to enter the dynamic job market with applicable knowledge, professionalism, and experience.

Introduction

The Masters of Science in Professional Science (MSPS) program is recognized by the Professional Science Masters (PSM) organization. It was introduced to Middle Tennessee State University through the efforts of Dr. Foroudastan in 2004. This unique and innovative two-year interdisciplinary program is designed for students who want to further their education in the 
STEM disciplines and develop valuable skills desired by the industry. ${ }^{5}$ Not only do students continue to develop science, engineering, and mathematical expertise, they learn vital business skills and knowledge needed to produce well prepared managers equipped to lead in their company.

With the growing competitiveness of the job market and the globalization of our economy, it's imperative that we prepare students to enter the workforce with excellent soft skills and professionalism. It's no longer enough to be solely technically savvy. Potential employees must also possess exceptional communication, leadership, and management skills. The success of the MSPS program is the result of the innovative courses which focus on grooming students to hone in on their soft skills along with technical skills. This is what sets MSPS graduate students apart from inexperienced students.

The MSPS program gives individuals who have a strong scientific background the option to integrate that knowledge with the business side of the STEM industry. This degree prepares its students for careers in academia, business, government, and nonprofit organizations. Students who do not wish to pursue a PhD have the opportunity to obtain a masters that will give them the science and business skills they desire to be successful in an industry setting.

\section{Program Description}

When the MSPS program was first established, it had three concentrations: Biostatistics, Biotechnology, and Healthcare Informatics. Due to the undeniable success it has generated, it now contains six different concentrations: Biostatistics, Biotechnology, Actuarial Science, Geosciences, Healthcare Informatics, and Engineering Management. ${ }^{5}$ All concentrations require the same business courses, but have their own specific core curriculum. Each individual concentration has a designated advisor that assists students in creating schedules, obtaining internships, and networking.

\section{Engineering Management Degree}

The Engineering Management degree includes courses that prepare students for leadership roles in the workplace. These courses focus heavily on project management skills, safety planning, research methods, and technology trends. Students also have the opportunity to obtain their Green Belt Certification through competing the Six Sigma course, which is a methodology defined as a comprehensive flexible system for achieving, sustaining, and maximizing business success. Through this class, students are exposed to hands-on projects that develop problemsolving skills used to define, measure, analyze, and improve business processes. ${ }^{6}$

Students also have the opportunity to receive their PMI certification, which prepares them for project management roles in safety planning, the concrete and automotive industry, process control companies, and technology transfer/research methods. Graduates leave this program being able to choose a career in many different types of occupations such as technology managers for manufacturing operations (both assembly and fabrication), healthcare, food production, training/consulting and government research initiatives. According to the Master of Science in Professional Science Institutional Effectiveness Achievements Report for the Fall 
2014 and Summer 2015 semesters, 100\% of the internship supervisors rated candidates as "equal" or "better than" a new employee at demonstrating the ability to utilize problem solving skills in a real world setting. ${ }^{4}$ This program continues to produce well rounded students who possess valuable skills demanded in the job market.

\section{Professional Skills}

In addition to advancing science based knowledge and skills, the soft skills that are necessary for industry success are further developed and practiced. Through group projects and presentations, students have the opportunity to focus on their team building, communication, leadership, and oral and written communication skills. These are abilities that are vital for success in the workplace as an engineering manager, director, or leader of any kind.

Throughout this degree, students are given ample amount of opportunities to practice and perfect their presentation and oral communication skills. At the conclusion of the internship, students are required to give a presentation to the MSPS students and faculty, and any other business professional that choose to attend. Along with that, students are required to present material in their specific curriculum classes and business courses. Students receive feedback not only on their presented material, but on their observed presentation skills, which gives them constructive criticism on how to keep improving.

\section{Observations}

The MSPS program holds affiliations with the College of Basic and Applied Sciences, College of Behavioral and Health Sciences, and the Jennings A. Jones College of Business to promote its interdisciplinary nature. Instead of hiring instructors with only science backgrounds to teach business focused courses, students are being educated by business professors who hold business degrees and have many years of experience in the field. ${ }^{6}$ For example, one of the business courses MSPS students are required to take is Managerial Communication. This course educates students on the importance of verbal and written communication in the workplace, how to properly compose letters/emails, and how to give professional presentations. Through successful collaborations, a business professor who works for the Jennings A. Jones College of Business teaches this course. By having certified business professors instruct these courses, students get a non-biased perspective about the business side of industry work. The MSPS program also partners with and maintains successful relationships with local industries. This encourages tours to be organized for students to learn what different industries focus on and if they are interested in that line of work. It is also an opportunity for students that participate in the tours to observe and take note of professional skills and conduct in the workplace.

\section{Results}

Before the student can graduate with an MSPS degree, the student must complete a 250-hour internship with a business that is related to their field of study. This internship replaces the traditional thesis requirement. While a thesis teaches the student work ethic and proper research skills, it lacks providing the student much needed hands-on experience he/she receives from real world industry exposure. ${ }^{3}$ Students develop problem-solving skills that can be applied to 
overcoming actual workplace obstacles and challenges. Based on the Institutional Effectiveness Survey, 100\% of students in Fall 2014, 80\% of students in Spring 2015, and 92\% of students in Summer 2015 agreed that the core business courses enhanced their internship experience. ${ }^{4}$ Because of the nature of the MSPS degree and this internship opportunity, it's as if students are given 2 years of professional experience before entering the job market.

Students are required to take this internship during their last semester to ensure they have obtained the necessary business skills and knowledge from their course work, and are able to apply that to the internship. Students not only form professional business connections, but also are given a chance to showcase their science and business acumen for a chance to have a job offer at the end of the internship. The internship shows the students how to apply their heart for science with a mind for business, and the impact their contributions can make in a real world setting.

Internship presentations consist of a PowerPoint presentation detailing the student's place of employment, job duties, work results, and overall reflection of the internship experience. Every student in the MSPS program is invited to view the presentations of their fellow classmates. This allows them to have an idea of what is expected when they go to work for an industry, and what kind of internships are available for each concentration. Student's viewing the presentations also have the opportunity to ask questions and network with any internship supervisors/advisors that attend.

Before the end of the internship, students interview a professional of their choice in their field of interest. This is a great opportunity for the scholar to reach out and connect with a successful individual, and ask them questions about their career path and what circumstances lead them to this line of work. Students are able to demonstrate their oral communication skills, and have an opportunity to learn the basics to conducting a professional interview.

A professional portfolio is also required of the student at the end of the internship experience. Included in the portfolio is a reflective essay that describes experiences and knowledge gained throughout the internship, weekly journals that students write over the course of the internship, along with a professional interview report. The professional portfolio is required so that students can reflect on their experience and build a better relationship with their employer. The portfolio can also help students when applying for jobs in the future.

\section{Exit Surveys}

MSPS students complete an anonymous exit survey at the end of the internship to give honest feedback about how the classes impacted their internship experience. Based on the exit survey given to students upon finishing the internship, $70 \%$ receive a job offer. ${ }^{7}$ The companies who provide the internship experiences see value in this program. In fact, Fall 2014 and Spring 2015 internship supervisors were asked how they would rate interns at problem solving compared to new employees who had not completed internships, and $100 \%$ of the internship supervisors rated MTSU interns better than new employees. ${ }^{4}$ In order to keep up this momentum, MTSU is continuously making new partnerships with employers who specifically look to hire MSPS students as interns and potential employees. 
Students found the combination of science and business courses are highly beneficial and prepared them for employment in an industry position. The table below displays the percent of students who agreed with the statement on the anonymous exit survey for the previous three semesters. $^{7}$

\begin{tabular}{|l|l|l|l|}
\hline ALL MSPS CONCENTRATIONS & Fall 2014 & $\begin{array}{l}\text { Spring } \\
2015\end{array}$ & $\begin{array}{l}\text { Summer } \\
2015\end{array}$ \\
\hline $\begin{array}{l}\text { Business courses enhanced role as a science } \\
\text { professional during internship }\end{array}$ & $100 \%$ & $80 \%$ & $92 \%$ \\
\hline $\begin{array}{l}\text { Major courses in area of study enhanced role as } \\
\text { a science professional during internship } \\
\text { experience }\end{array}$ & $90 \%$ & $85 \%$ & $95 \%$ \\
\hline $\begin{array}{l}\text { Courses provided information needed to succeed } \\
\text { in a business environment }\end{array}$ & $100 \%$ & $90 \%$ & $82 \%$ \\
\hline \begin{tabular}{l} 
Would recommend this program to others \\
\hline
\end{tabular} & $100 \%$ & $95 \%$ & $100 \%$ \\
\hline
\end{tabular}

Table 1. MSPS Graduate Exit Survey

Awards and Recognition

As a result of the satisfaction of past students and employers, the MSPS program has been recognized locally and nationally. In 2010, the program was granted the Tennessee Board of Regents (TBR) Academic Excellence Award for its promotion of math and science and its unique contributions to the community and state. ${ }^{3}$ It has also been acclaimed as a model program by the Council of Graduate Schools in Washington, D.C.as a promising example of interdisciplinary efforts to strengthen the student's professional skills. ${ }^{2}$

\section{Discussion}

MTSU offers a Master of Science in Engineering Technology with concentrations in Engineering Technology and Occupational Health and Safety. ${ }^{1}$ Like the Engineering Management concentration in the MSPS program, the Engineering Technology degree offers students the chance to develop their project planning, safety planning, and research skills. However, the MSPS Engineering Management degree is focused more on developing management skills through required business courses, research skills, and they also obtain certificates in Lean Manufacturing and Six Sigma. In general an Engineering Technology degree may require a thesis, whereas the Engineering Management concentration requires an internship. According to the exit surveys, students found internships to be more beneficial than a thesis when applying for jobs in industry. Both degrees are extremely beneficial. However, the Engineering Management concentration is focused on students who want to hold management and leadership positions in the future. 
Future work

The Masters of Science in Professional Science program will continue to maintain and build upon effective training of written communication skills, problem solving skills, and place importance upon effective oral communication skills. Based on student feedback found in the MSPS program Institutional Effectiveness Survey, the program will also strive to incorporate science field material and problem solving situations in courses such as accounting and business law for concentrations such as Engineering Management. ${ }^{4}$ The MSPS program is also always seeking new and beneficial industry partnerships and support for students in this fast growing program.

\section{Conclusions}

The Masters of Science in Professional Science program's goal is to fill the gap in industry environments between the scientist and the business professional. This unique and innovative curriculum primes students to be able to communicate scientifically, while understanding fundamental business practices. Some employees may only focus on one particular talent he/she can bring to the table, but that philosophy is not enough anymore to maintain a competitive edge in this global economy. More than ever, it is critical recent graduates are entering the workforce literate and capable of getting the job done efficiently and accurately. Some find it difficult landing jobs after they receive their undergraduate degree because they do not possess the necessary amount of experience required for the job. This program transforms young individuals from having limited to no real world experience, to qualified young professionals with the necessary skills to succeed.

Bibliography

[1]Engineering Technology, Engineering Technology Concentration, M.S. (2016, February 26). Retrieved March 24, 2016, from http://catalog.mtsu.edu/preview_program.php?catoid=19\&poid=5815\&returnto=2677

[2] Graduate Education: The Backbone of American Competitiveness and Innovation. (2007). In Council of Graduate Schools

[3] Foroudastan, S. (2014). Engineering Management Creating Strong Partnerships between Future Graduates. Proceedings of the 2014 Conference for Industry and Education Collaboration, American Society for Engineering Education, 1-10.

[4] Foroudastan, S. (2015). Master of Science in Professional Science 2014-2015 Institutional Effectiveness Achievements Report. Middle Tennessee State University.

[5] Foroudastan, S. (2015). Domestic Internationalization Developed Through Collegiate Activities. Proceedings of the 2015 American Society for Engineering Education Annual Conference and Exposition. 
[6] Foroudastan, S. (2013). Engineering Management an Innovative Interdisciplinary Master's Program Preparing Students for Challenging Careers. International Journal for Management Science and Technology, 1(5).

[7] Foroudastan, S. (2015). Master of Science in Professional Science Exit Survey. Middle Tennessee State University. 